\title{
Partial Parallel Dual Active Bridge Converter with Variable Voltage Gain for SOEC/SOFC System
}

\author{
Xiao, Yudi; Zhang, Zhe; Andersen, Michael A. E.; Thomsen, Brian Engelbrecht
}

Published in:

Proceedings of 34th annual IEEE Applied Power Electronics Conference and Exposition

Link to article, DOI:

10.1109/APEC.2019.8721864

Publication date:

2019

Document Version

Peer reviewed version

Link back to DTU Orbit

Citation (APA):

Xiao, Y., Zhang, Z., Andersen, M. A. E., \& Thomsen, B. E. (2019). Partial Parallel Dual Active Bridge Converter with Variable Voltage Gain for SOEC/SOFC System. In Proceedings of 34th annual IEEE Applied Power Electronics Conference and Exposition (pp. 1641-1646). IEEE. https://doi.org/10.1109/APEC.2019.8721864

\section{General rights}

Copyright and moral rights for the publications made accessible in the public portal are retained by the authors and/or other copyright owners and it is a condition of accessing publications that users recognise and abide by the legal requirements associated with these rights.

- Users may download and print one copy of any publication from the public portal for the purpose of private study or research.

- You may not further distribute the material or use it for any profit-making activity or commercial gain

- You may freely distribute the URL identifying the publication in the public portal 


\title{
Partial Parallel Dual Active Bridge Converter with Variable Voltage Gain for SOEC/SOFC System
}

\author{
Yudi Xiao ${ }^{1,2}$, Zhe Zhang ${ }^{1}$, Michael A. E. Andersen ${ }^{1}$, Brian Engelbrecht Thomsen ${ }^{2}$ \\ ${ }^{1}$ Department of Electrical Engineering, Technical University of Denmark, Kgs. Lyngby, Denmark \\ ${ }^{2}$ Welltec A/S, Alleroed, Denmark \\ zz@elektro.dtu.dk
}

\begin{abstract}
Fuel cells are becoming one of the promising devices in distributed generation (DG) systems due to their modularity, low or zero pollution and dispatchability. As one of the fuel cell technologies, solid oxide electrolysis cell / solid oxide fuel cell (SOEC/SOFC) has gained more and more attention owing to their relatively high efficiency. However, design of the interface system for SOEC/SOFC is challenging because of the current-dependent and low stack voltage, the slow cell dynamics and transient response, and the asymmetrical power characteristic of SOEC/SOFC. In this paper, a self-circulating modulation (SCM) is proposed for the partial parallel dual active bridge $\left(\mathrm{P}^{2} \mathrm{DAB}\right)$ converter. The $S C M$ makes the voltage gain of the $P^{2} D A B$ converter variable, given the inherent high voltage gain characteristics of the topology itself, the $P^{2} D A B$ converter with SCM can thereby address the current-dependent and low stack voltage issues of SOEC/SOFC. Moreover, by using a SOFC-Parallel-SOEC-Series interface architecture, the asymmetrical power characteristics of SOEC/SOFC do not degrade the efficiency of the $P^{2} D A B$ converter. Finally, the analysis of the proposed $S C M$ is verified on a $1 \mathrm{MHz}, 500 \mathrm{~W}$, $400 \mathrm{~V} / 50 \mathrm{~V}$, GaN-based $P^{2} \mathrm{DAB}$ converter.
\end{abstract}

Keywords-Reversible fuel cells, power converter, dual active bridge, GaN

\section{INTRODUCTION}

Fuel cells are energy conversion devices that convert the chemical energy of fuel directly into electrical energy [1]. It is becoming one of the promising devices in distributed generation (DG) systems. Because fuel cells can be modularly implemented, fuel cell systems can be built in small size and then be placed close to electrical loads, enabling the thermal energy as a byproduct of the reaction to be used for cogeneration applications, making the combined efficiency attractive [2]. Due to its improved efficiency and low or nocarbon fuel sources, fuel cell systems typically generate low pollution. Besides, as a dispatchable DG unit, fuel cell systems are considered to be more reliable and more flexible in operation than non-dispatchable DG units such as wind or photovoltaic systems [3]. Furthermore, fuel cell systems can also be used to buffer the intermittent energy generated by renewable energy resources such as wind and solar to help ensure a high reliability of DG systems [4].

As one of the fuel cell technologies, solid oxide fuel cell (SOFC) produces electricity directly from oxidizing a fuel. If the same SOFC can also be used for electrolysis process, it is known as reversible SOFC, or combined solid oxide electrolysis cell / solid oxide fuel cell (SOEC/SOFC) [5]. The key feature of SOEC/SOFC systems is the high operating temperature, which is usually around 600-1000 Celsius degree. This high operating temperature simplifies the system configuration of SOFC by permitting internal reforming, facilitates the development of cogeneration systems [6] and

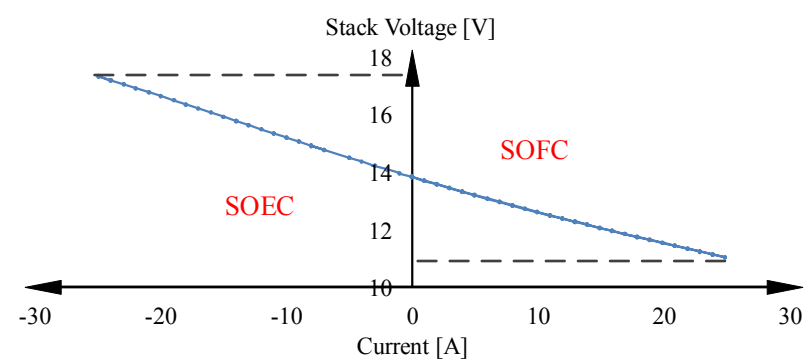

Fig. 1. Typical I-V curve of SOEC/SOFC

increases the electrical-to-chemical conversion efficiency of SOEC [7].

Bidirectional power electronics converters are the enabling technology facilitating the interface of SOEC/SOFC to the DG systems. Specifications of the converters need to be decided according to the characteristics of SOEC/SOFC. Fig. 1 shows the I-V curve of a SOEC/SOFC stack composed of 14 cells. Design of the bidirectional converters is challenging due to the current-dependent and low stack voltage [8], the slow cell dynamics and transient response [9], and the asymmetrical power characteristic of SOEC/SOFC [10].

A large number of converter topologies and control strategies have been proposed to address the currentdependent and low stack voltage issues of SOEC/SOFC. In [11], a full bridge $\mathrm{dc} / \mathrm{dc}$ converter with a transformer composed by multiple windings was proposed for the interface of grid-tied SOFC. The windings on the high voltage side of the transformer can be separately disconnected, therefore, the converter has a variable voltage gain to ensure efficient operation over a wide input voltage, which is the stack voltage of the SOFC. In [12], instead of having multiple transformer windings in series on the high voltage side as proposed in [11], several full bridges were connected in parallel on the low voltage side. Through disabling some of the full bridges on the low voltage side, variable voltage gain was achieved to meet efficiency goals in the interfacing of SOFC. In [13], a two-stage conversion structure was applied for the application of SOEC/SOFC. A CLLC resonant converter was used to achieve high voltage gain, and an interleaved buck converter was employed control the output voltage, which is the voltage of the stacked cells. By implementing close-loop control to the above proposed converters, the slow cell dynamics and transient response issues can be addressed. However, addressing the SOEC/SOFC's asymmetrical power characteristics issue is challenging due to the symmetrical power characteristics of the power converters themselves [10]. In [10], a new architecture was proposed to deal with the asymmetrical power characteristics of SOEC/SOFC. Instead of connecting 


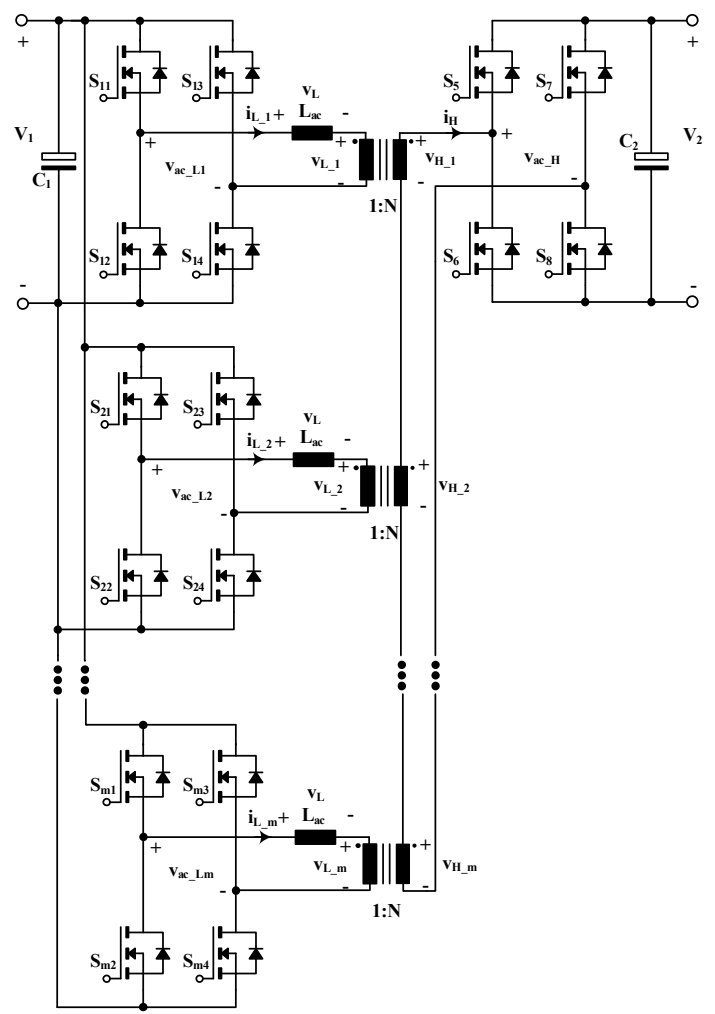

Fig. 2. Topology of the $\mathrm{P}^{2} \mathrm{DAB}$ converter

converters to stacks in parallel at both of the SOEC and SOFC modes, the converter is put in parallel to the stacks in SOFC mode, and in series to the stacks in SOEC mode. With this novel architecture, the operating power of the converters becomes much more symmetrical.

In [14], a partial parallel dual active bridge $\left(\mathrm{P}^{2} \mathrm{DAB}\right)$ converter was proposed. The $\mathrm{P}^{2} \mathrm{DAB}$ converter has high voltage gain which makes it potentially suitable for the interface of SOEC/SOFC to the grid. In this paper, in order to address the current-dependent stack voltage issues, a selfcirculating modulation (SCM) is proposed for the $\mathrm{P}^{2} \mathrm{DAB}$ converter. And by using the SOFC-parallel-SOEC-series architecture proposed in [10], the asymmetrical power characteristics of SOEC/SOFC do not degrade the efficiency of the $\mathrm{P}^{2} \mathrm{DAB}$ converter.

This paper is organized as follows. After this introduction, the topology and the basic phase shift modulation (PSM) of the $\mathrm{P}^{2} \mathrm{DAB}$ converter is reviewed. In section III, the SCM of the $\mathrm{P}^{2} \mathrm{DAB}$ converter and the SOFC-parallel-SOEC-series architecture are introduced for the interface of SOEC/SOFC to the grid. In section IV, the advantages and the drawbacks of the proposed interface system for SOEC/SOFC are discussed. Finally, in section V, the theoretical analysis of the SCM is verified on a $1 \mathrm{MHz}, 500 \mathrm{~W}$ GaN-based $\mathrm{P}^{2} \mathrm{DAB}$ converter. Conclusions are made in section VI.

\section{TOPOlOGY AND PHASE SHIFT OPERATION OF THE $\mathrm{P}^{2} \mathrm{DAB}$ CONVERTER}

Fig.2 gives the topology of the $\mathrm{P}^{2} \mathrm{DAB}$ converter. By operating the $m$ transformers in parallel on the low voltage side (LVs) and in series on the high voltage side (HVs),

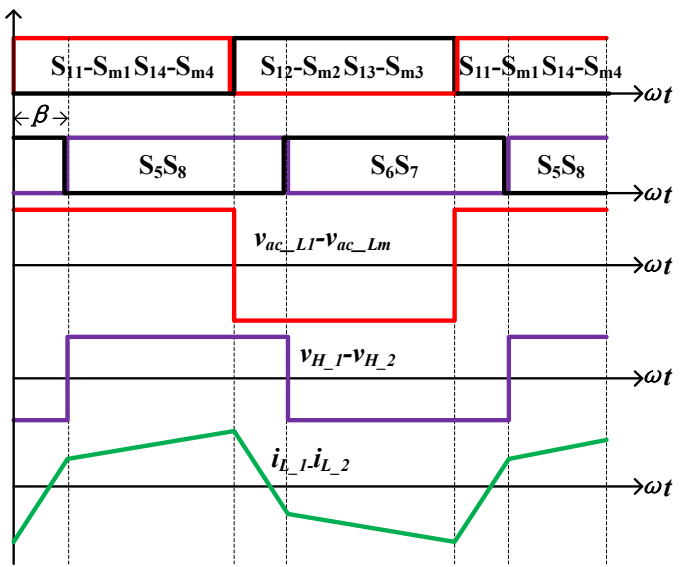

Fig. 3. Typical waveforms of the $\mathrm{P}^{2} \mathrm{DAB}$ converter with PSM

the $\mathrm{P}^{2} \mathrm{DAB}$ converter features high current-rating on the LVs and high voltage gain. The basic modulation strategy of the $\mathrm{P}^{2} \mathrm{DAB}$ converter is PSM, whose typical waveforms are given in Fig. 3. Phase shift $\beta$ is added between the full-bridges on the LVs and the full-bridge on the HVs. Due to the series connection of the transformers on the HVs, the ac components of the currents $i_{L_{-} l} \sim i_{L_{-} m}$ are forced to be the same.

\section{Self-Circulating Modulation Of THE $\mathrm{P}^{2} \mathrm{DAB}$ CONVERTER AND THE SOFC-PARALLEL-SOEC-SERIES ARCHITECTURE}

\section{A. Self-Circulating Modulation of the $P^{2} D A B$ Converter}

With PSM, every full bridges on the LVs of the $\mathrm{P}^{2} \mathrm{DAB}$ converter are transferring power. All of the transformers contributes to boosting voltage. This full-voltage-gain operation is suitable for interfacing the SOEC/SOFC system operating in SOFC mode at full power, at which the stack voltage is the lowest, as shown in Fig. 1. However, when the power is decreased in SOFC mode, the stack voltage increases. Since $V_{2}$ is clamped to be the grid voltage, it is thereby necessary to change the voltage gain of the $\mathrm{P}^{2} \mathrm{DAB}$ converter in order to keep the voltage-matching between the stack voltage and the referred grid voltage. Voltage-matching implies that $V_{l}$ and the referred $V_{2}$ are nearly the same. For DAB based converters, the optimal operating point occurs when voltage-matching is realized [15].

Therefore, the SCM is proposed for the $\mathrm{P}^{2} \mathrm{DAB}$ converter to change its voltage gain. Fig. 4 gives the typical waveforms of the $\mathrm{P}^{2} \mathrm{DAB}$ converter with SCM for a half of the fullvoltage-gain. As shown, by disabling half of the $m$ full-bridges on the LVs, the voltage-matching is maintained even when $V_{l}$ (stack voltage) doubles. This disabling is realized by keeping both low side switches in on-state. Since the currents $i_{L_{-}} i_{L_{-} m}$ are forced to be the same, there are circulating currents in the low side switches even though the full bridges they belong to are not transferring power. Therefore, additional conduction losses are generated.

Assume that $n$ of the $m$ full-bridges on the LVs are modulated in self-circulating, the remaining $m-n$ full-bridges are modulated to have the same phase shift to the full-bridge on the HVs. The sum of the voltage across the winding on the HVs of the transformer is the voltage across the switching node of the full bridge on the HVs as expressed in (1). 


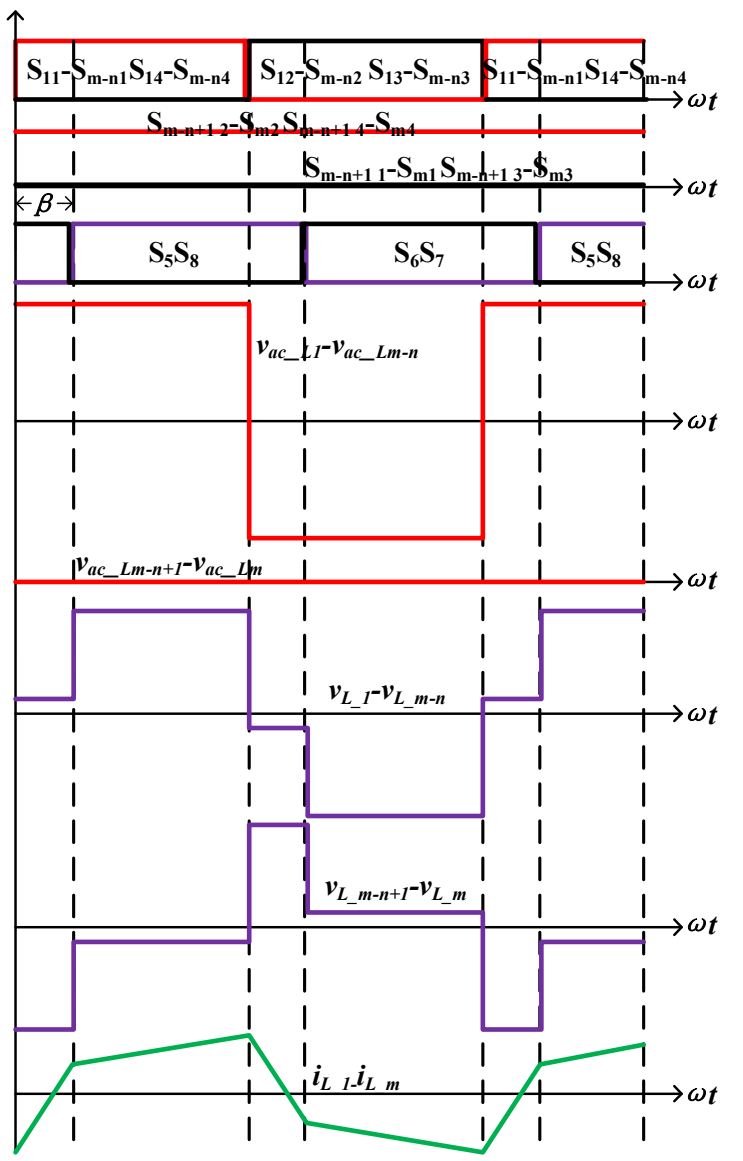

Fig. 4. Typical waveforms of the $\mathrm{P}^{2} \mathrm{DAB}$ converter with SCM for a half of the full-voltage-gain

$$
(m-n) v_{H_{-1}: m-n}+n v_{H_{-} m-n+1}: m=v_{a c_{-} H}
$$

In the enabled branches, the voltages across the inductors are expressed by:

$$
v_{L}=v_{a c_{-} L}-\frac{v_{H_{-1}: m-n}}{N}
$$

In the disabled branches, the voltage across the winding on the LVs of the transformer is the opposite to $v_{L}$, which is:

$$
v_{L_{-} m-n+1}: m=\frac{v_{H_{-} 1}: m-n}{N}-v_{a c_{-} L}
$$

Therefore, (4) can be obtained.

$$
v_{H_{-} m-n+1}: m=v_{H_{-1}: m-n}-N v_{a c_{-} L}
$$

Substitute (4) into (1), the expression of the voltage across the LVs winding of the $m-n$ enabled transformers can be obtained as in (5).

$$
v_{L_{-} 1}=v_{L_{-} 2}=\cdots=v_{L_{-} m-n}=\frac{v_{a c_{-} H}}{N m}+\frac{n}{m} v_{a c_{-L 1}: m-n}
$$

The voltage-matching-ratio $V M R$ can be expressed by (6).

$$
V M R=\frac{V_{L_{-1}}}{V_{a c_{-L 1}: m-n}}=\frac{V_{L_{-2}}}{V_{a c_{-L 1}: m-n}}=\cdots=\frac{V_{L_{-} m-n}}{V_{a c_{-L 1}: m-n}}=\frac{V_{2}}{N m V_{a c_{-L 1}: m-n}}+\frac{n}{m}
$$

When operating at the lowest stack voltage $V_{1 \min }, n$ equals to 0 . The initial voltage-matching-ratio $V M R i$ can be defined as (7).

$$
V M R i=\frac{V_{2}}{N m V_{1 \min }}
$$

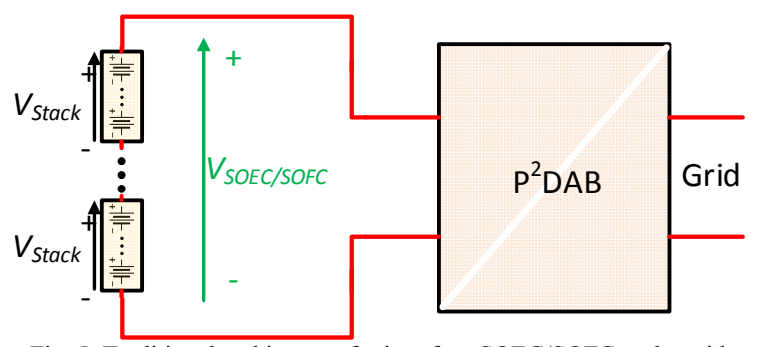

Fig. 5. Traditional architecture for interface SOEC/SOFC to the grid

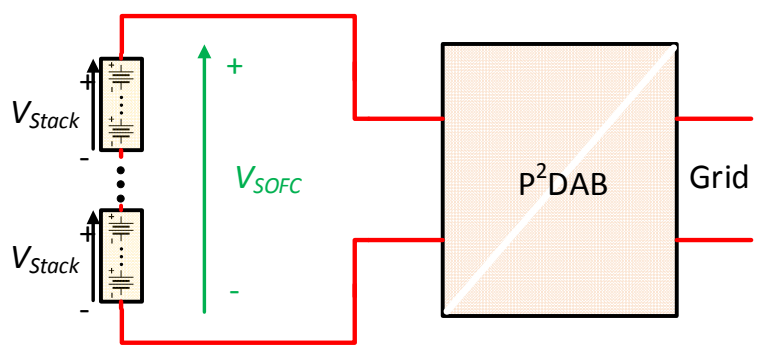

(a)SOFC mdoe

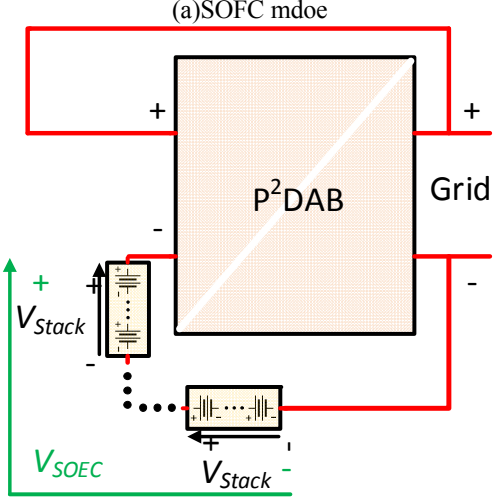

(b)SOEC mode

Fig. 6. SOFC-Parallel-SOEC-Series architecture proposed in [10]

From (6) and (7), if $n$ keeps to be 0 when the stack voltage increases, $V M R$ will deviate from $V M R i$, which means that the converter lose voltage-matching. (8).

By combining (6) and (7), VMR can then be expressed by

$$
V M R=V M R i \frac{V_{1 \min }}{V_{a c_{-L 1}: m-n}}+\frac{n}{m}
$$

From (8), by increasing $n$, the decrement of the first term of $V M R$ due to the increased stack voltage can be compensated by the increment of the second term. The voltage-matching under variable stack voltages can be guaranteed.

\section{B. SOFC-Parallel-SOEC-Series Architecture for SOEC/SOFC System}

The proposed SCM makes the voltage gain of the $\mathrm{P}^{2} \mathrm{DAB}$ converter adjustable to deal with the varying stack voltage of SOEC/SOFC. Since decreasing the voltage gain of the $\mathrm{P}^{2} \mathrm{DAB}$ converter by SCM is achieved by disabling some of the full bridges, the maximum power that can flow through the converter is decreased along with the reducing of the voltage gain. Fig. 5 shows the traditional architecture interfacing $\mathrm{SOEC} / \mathrm{SOFC}$ to the grid. If this traditional architecture is utilized for interfacing and the SCM is used to ensure voltage matching over the entire operating area, the number of branches that are enabled to handle the maximum power flow, 
which happens in the SOEC mode, is actually the minimum. While all of the branches are enabled to deliver just half of the maximum power of SOEC/SOFC. Therefore, with the traditional interfacing architecture, it is very challenging in the design of a high efficiency $\mathrm{P}^{2} \mathrm{DAB}$ converter for the entire operating area.

Fig. 6 shows the SOFC-Parallel-SOEC-Series architecture proposed in [10]. With this new architecture, the powerhandling problems mentioned in the last paragraph are sloved.

For the SOFC mode, the configuration is the same as the traditional one shown in Fig. 5, where the stacks are connected to the $\mathrm{P}^{2} \mathrm{DAB}$ converter in parallel. At the highest power, the stack voltage is the lowest. All of the branches are enabled for the highest voltage gain and the strongest power flow capability. As the power decreases, more and more branches are disabled to keep the voltage-matching. And since the enabled branches still operates in high power, the zero voltage switching (ZVS) is guaranteed even though the converter itself is at low power.

For the SOEC mode, the configuration is different to the traditional one. The stacks are connected in series with the $\mathrm{P}^{2} \mathrm{DAB}$ converter, and then this series connection is connected in parallel to the grid. As a result, the I-V curve of the LVs of the $\mathrm{P}^{2} \mathrm{DAB}$ converter will have drooping characteristics as in the SOFC mode. Therefore, voltage-matching and ZVS can also be achieved at low power operating area of SOEC mode. Moreover, when $V_{S O E C}$ is half of the grid voltage, the $\mathrm{P}^{2} \mathrm{DAB}$ converter have symmetrical power rating in both operation modes.

\section{AdVAntages AND DraWbacks OF THE PROPOSED INTERFACE SYSTEM FOR SOEC/SOFC}

Comparison is made between the proposed interface system, which is the SOFC-Parallel-SOEC-Series architecture using the $\mathrm{P}^{2} \mathrm{DAB}$ converter with SCM, and the traditional architecture using the $\mathrm{P}^{2} \mathrm{DAB}$ converter with PSM.

The advantages of the proposed interface system include:

- Voltage-matching of the $\mathrm{P}^{2} \mathrm{DAB}$ converter is ensured for the entire operating area.

- Zero voltage switching of the $\mathrm{P}^{2} \mathrm{DAB}$ converter is guaranteed at low power.

- Switching losses in the disabled branches are zero.

- Symmetrical power rating of the $\mathrm{P}^{2} \mathrm{DAB}$ converter is achieved in both SOEC mode and SOFC mode.

- The power rating of the $\mathrm{P}^{2} \mathrm{DAB}$ converter is reduced.

The drawbacks of the proposed interface system include:

- Additional conduction losses are generated in the disabled branches.

\section{EXPERIMENTS}

In order to verify the proposed SCM for the $\mathrm{P}^{2} \mathrm{DAB}$ converter, a hardware prototype with two full-bridges on the LV side was built as will be described in this section. The implemented $400 \mathrm{~V} / 50 \mathrm{~V} \mathrm{P}{ }^{2} \mathrm{DAB}$ converter is depicted in Fig. 7. The system is rated for $500 \mathrm{~W}$ and exhibits a total volume of $378 \mathrm{~cm}^{3}$ which corresponds to a power density of $1.3 \mathrm{~W} / \mathrm{cm}^{3}$.

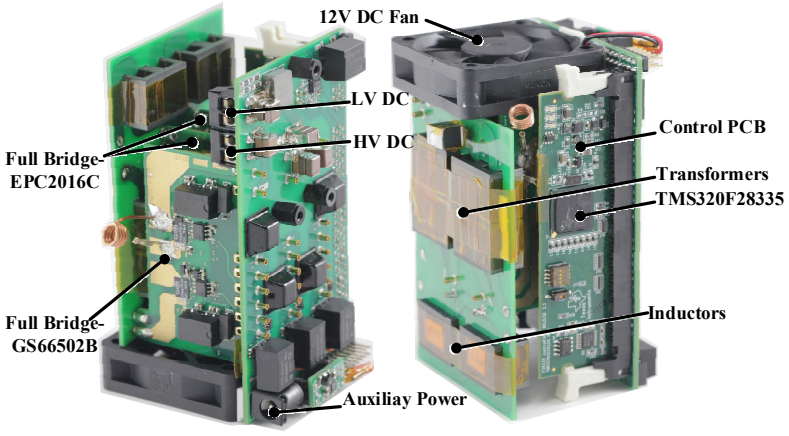

Fig. 7. Picture of the $\mathrm{P}^{2} \mathrm{DAB}$ hardware taken from different perspectives

TABLE I. TeChNicAl Details of the P²DAB Prototype

\begin{tabular}{|c|c|c|}
\hline & Description & Parameter \\
\hline \multirow{4}{*}{$\begin{array}{l}\text { Specifications } \\
\text { of the prototype }\end{array}$} & $\begin{array}{l}\text { Switching } \\
\text { Frequency }\end{array}$ & $1 \mathrm{MHz}$ \\
\hline & $\begin{array}{c}\text { DC voltage on } \\
\text { the HV side }\end{array}$ & $400 \mathrm{Vdc}$ \\
\hline & $\begin{array}{l}\text { DC voltage on } \\
\text { the LV side }\end{array}$ & $50 \mathrm{Vdc}$ \\
\hline & $\begin{array}{c}\text { Maximum } \\
\text { power }\end{array}$ & $530 \mathrm{~W}$ \\
\hline \multirow{2}{*}{$\begin{array}{c}\text { Power } \\
\text { semiconductor }\end{array}$} & $\begin{array}{c}\text { Switches on the } \\
\text { HV side }\end{array}$ & GS66502B \\
\hline & $\begin{array}{c}\text { Switches on the } \\
\text { LV side }\end{array}$ & EPC2016C \\
\hline \multirow{4}{*}{ Transformer } & $\begin{array}{l}\text { Material for the } \\
\text { core }\end{array}$ & ML91S \\
\hline & $\begin{array}{l}\text { Dimension of } \\
\text { the core }\end{array}$ & $2 \times$ EE-21.8-11.4-15.8 \\
\hline & $\begin{array}{l}\text { Number of turns } \\
\text { on the HV side }\end{array}$ & 8 \\
\hline & $\begin{array}{l}\text { Number of turns } \\
\text { on the LV side }\end{array}$ & 2 \\
\hline \multirow{3}{*}{ Inductor } & $\begin{array}{l}\text { Material for the } \\
\text { core }\end{array}$ & ML91S \\
\hline & $\begin{array}{l}\text { Dimension of } \\
\text { the core }\end{array}$ & $1 \times$ EE-21.8-11.4-15.8 \\
\hline & Number of turns & 1 \\
\hline \multirow{2}{*}{ DC capacitors } & $\begin{array}{c}\text { DC capacitor on } \\
\text { the HV side }\end{array}$ & $20 \times$ CKG57NX7T2J105M500JH \\
\hline & $\begin{array}{c}\text { DC capacitor on } \\
\text { the LV side }\end{array}$ & $63 \times \mathrm{C} 2220 \mathrm{C} 105 \mathrm{~K} 1 \mathrm{R} 1 \mathrm{C} 7186$ \\
\hline Cooling system & Fan & MC35357 \\
\hline
\end{tabular}

As it can be seen from the picture, the converter is realized by means of six individual PCBs, which include three full-bridge PCBs equipped with GaN switches and their driving circuits, one digital control board based on TMS320F28335, one baseboard equipped with power connectors and detecting circuits, and one PCB winding board. In order to extract losses from the power electronics, a $5 \mathrm{~cm} \times 5 \mathrm{~cm} \times 1 \mathrm{~cm} 12 \mathrm{~V}$ DC fan is mounted. No heat sink was attached to the PCBs, the heat generated in the semiconductors is spread by the PCB and quickly dissipated into the air with the help of the fan. Technical details of this prototype are given in Table I.

The wavefroms of the $\mathrm{P}^{2} \mathrm{DAB}$ converter operating at $530 \mathrm{~W}$ output power and $400 \mathrm{~V} / 50 \mathrm{~V}$ rated voltage are shown in Fig. 8. The waveforms are labeled according to the circuit schematic shown in Fig. 2. As shown in Fig. 8, the waveforms have the same pattern as those in Fig. 3, except $v_{a c} H$ and $v_{d s}$ of GS66502B, which ramp up/down too slowly. The ZVS of GS66502B is thereby not achieved. This slow switching is mainly due to the poor PCB layout. 


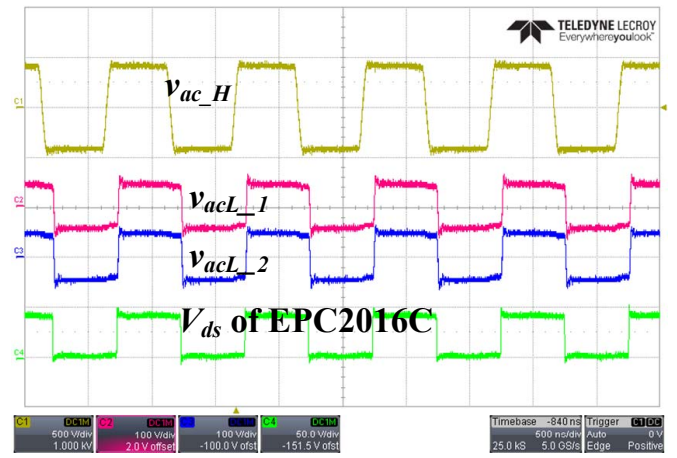

(a)Voltage waveforms of the high frequency link and the drain-source voltage of EPC2016C

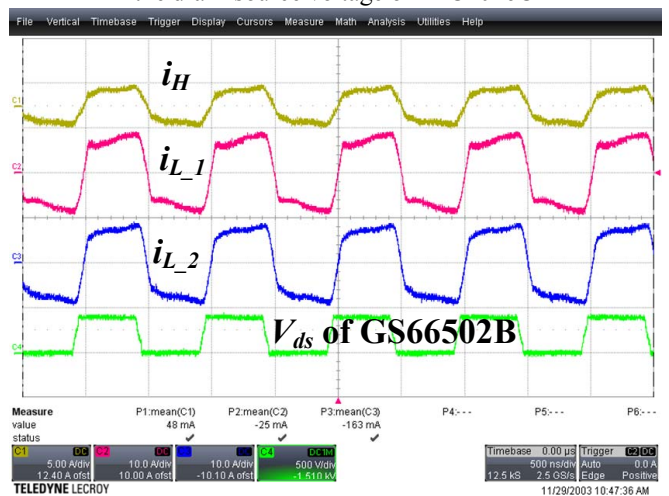

(b)Current waveforms of the high frequency link and the drain-source voltage of GS66502B

Fig. 8. Experimental waveforms of the $\mathrm{P}^{2} \mathrm{DAB}$ converter operating at $530 \mathrm{~W}$ output power and $400 \mathrm{~V} / 50 \mathrm{~V}$ rated voltage (Time: $500 \mathrm{~ns} / \mathrm{div}$ )

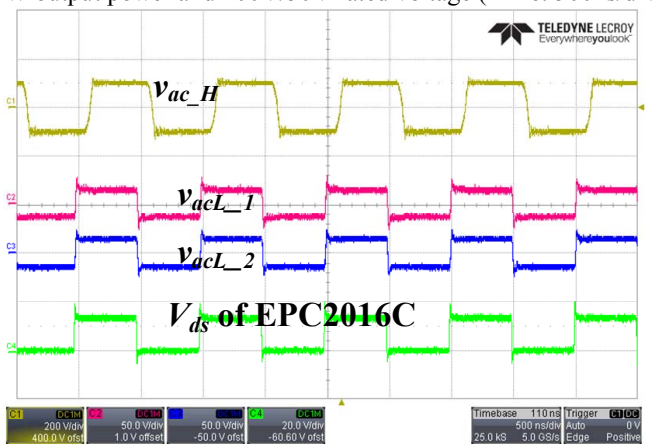

(a)Voltage waveforms of the high frequency link and the drain-source voltage of EPC2016C

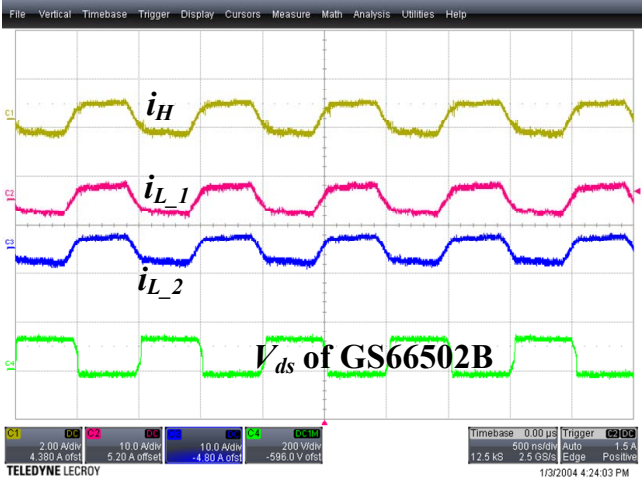

(b)Current waveforms of the high frequency link and the drain-source voltage of GS66502B

Fig. 9. Waveforms of the $\mathrm{P}^{2} \mathrm{DAB}$ converter with SCM under full voltage gain, $14 \mathrm{~V} / 100 \mathrm{~V}$ (Time: $500 \mathrm{~ns} / \mathrm{div}$ )

The waveforms which show the variable voltage gain operation of the $\mathrm{P}^{2} \mathrm{DAB}$ converter with $\mathrm{SCM}$ are given in Fig.

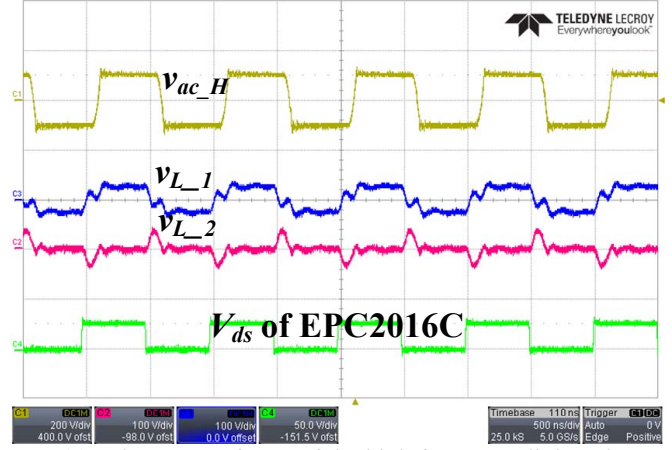

(a)Voltage waveforms of the high frequency link and the drain-source voltage of EPC2016C

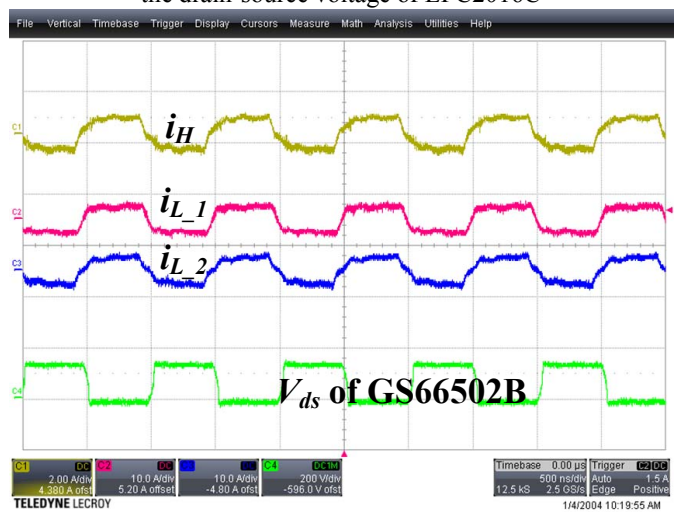

(b)Current waveforms of the high frequency link and the drain-source voltage of GS66502B

Fig. 10. Waveforms of the $\mathrm{P}^{2} \mathrm{DAB}$ converter with SCM under half of the full voltage gain, $28 \mathrm{~V} / 100 \mathrm{~V}$ (Time: $500 \mathrm{~ns} / \mathrm{div}$ )

9 and Fig. 10. The $\mathrm{P}^{2} \mathrm{DAB}$ converter is first operated with PSM in order to have the so-called full voltage gain. As shown in Fig. 9, with $V_{l}=14 \mathrm{~V}$ as the input and $V_{2}=100 \mathrm{~V}$ as the output , the prototype has a voltage gain around 7 . And the voltagematching is achieved as can be seen from the trapezoidal current waveforms.

The $\mathrm{P}^{2} \mathrm{DAB}$ converter is then operated with $\mathrm{SCM}$ in order to change the voltage gain. As shown in Fig. 10, with $V_{l}=28 \mathrm{~V}$ as the input and $V_{2}=100 \mathrm{~V}$ as the output, the voltage-matching is still kept by decreasing the voltage gain to around 3.5. Compared with the theoretical waveforms in Fig. 4, clearly visible is that the experimental waveforms in Fig. 10 show the same pattern. Therefore, the analysis of the SCM operation is verified. Compared with the measured current waveforms in full gain operation in Fig. 9(b), the measured current waveforms in half gain operation in Fig. 10(b) have more oscillations.

\section{CONCLUSIONS}

In this paper, a self-circulating modulation (SCM) is proposed for the Partial Parallel Dual Active Bridge $\left(\mathrm{P}^{2} \mathrm{DAB}\right)$ converter. With the SCM, the voltage gain of the $\mathrm{P}^{2} \mathrm{DAB}$ converter can be adjusted to guarantee the voltage-matching under wide input/output voltage ranges. By using the $\mathrm{P}^{2} \mathrm{DAB}$ converter with SCM in a novel SOFC-Parallel-SOEC-Series architecture, challenges of designing interface system for SOEC/SOFC due to its current-dependent and low stack voltage and its asymmetrical power characteristic can be addressed. The SCM operation of the $\mathrm{P}^{2} \mathrm{DAB}$ converter is verified on a $1 \mathrm{MHz}, 500 \mathrm{~W}, 400 \mathrm{~V} / 50 \mathrm{~V}$, GaN-based $\mathrm{P}^{2} \mathrm{DAB}$ converter. 


\section{REFERENCES}

[1] H. Nehrir, Caisheng Wang and S. R. Shaw, "Fuel cells: promising devices for distributed generation," in IEEE Power and Energy Magazine, vol. 4, no. 1, pp. 47-53, Jan.-Feb. 2006.

[2] J. Lai and M. W. Ellis, "Fuel Cell Power Systems and Applications," in Proceedings of the IEEE, vol. 105, no. 11, pp. 2166-2190, Nov. 2017.

[3] J. Kennedy, P. Ciufo and A. Agalgaonkar, "Intelligent load management in Microgrids," 2012 IEEE Power and Energy Society General Meeting, San Diego, CA, 2012, pp. 1-8.

[4] M. Farhadi and O. Mohammed, "Energy Storage Technologies for High-Power Applications," in IEEE Transactions on Industry Applications, vol. 52, no. 3, pp. 1953-1961, May-June 2016.

[5] R. Ma, F. Gao, E. Breaz, Y. Huangfu and P. Briois, "Multidimensional Reversible Solid Oxide Fuel Cell Modeling for Embedded Applications," in IEEE Transactions on Energy Conversion, vol. 33, no. 2, pp. 692-701, June 2018.

[6] M. W. Ellis, M. R. Von Spakovsky and D. J. Nelson, "Fuel cell systems: efficient, flexible energy conversion for the 21 st century," in Proceedings of the IEEE, vol. 89, no. 12, pp. 1808-1818, Dec. 2001.

[7] N. Q. Minh, M. B. Mogensen, "Reversible solid oxide fuel cell technology for green fuel and power production," in the Electrochemical Society Interface, vol. 22, no. 4, pp. 55-62, Winter 2013.

[8] L. M. P. Fanjul, "Design considerations for dc-dc converters in fuel cell systems," PhD Dissertation, Texas A\&M University, Dec 2006.
[9] Z. Zhang, R. Pittini, M. A. E. Andersen, O. C. Thomsen, "A review and design of power electronics converters for fuel cell hybrid system applications," in Energy Procedia, 20, pp. 301-310, 2012.

[10] K. T. Manez, A. Anthon, Z. Zhang, "High efficiency power converter for a doubly-fed SOEC/SOFC system", in 2016 IEEE Applied Power Electronics Conference and Exposition (APEC), pp. 1235-1242, Mar. 2016.

[11] L. Zubieta and G. Panza, "A wide input voltage and high efficiency DC-DC converter for fuel cell applications," Twentieth Annual IEEE Applied Power Electronics Conference and Exposition, 2005. APEC 2005., Austin, TX, 2005, pp. 85-89 Vol. 1.

[12] K. Sternberg and Hongwei Gao, "A new DC/DC converter for solid oxide fuel cell powered residential systems," 2008 34th Annual Conference of IEEE Industrial Electronics, Orlando, FL, 2008, pp. 2273-2277.

[13] X. Lin, K. Sun, J. Lin, Z. Zhang and W. Kong, "A Multi-Port Bidirectional Power Conversion System for Reversible Solid Oxide Fuel Cell Applications," 2018 International Power Electronics Conference (IPEC-Niigata 2018 -ECCE Asia), Niigata, Japan, 2018, pp. 3460-3465.

[14] Z. Zhang, K. T. Manez, Y. D. Xiao, M. A. E. Andersen, "High voltage gain dual active bridge converter with an extended operation range for renewable energy systems", in 2018 IEEE Applied Power Electronics Conference and Exposition (APEC), pp. 1865-1870, Mar. 2018.

[15] G. Xu, D. Sha, Y. Xu and X. Liao, "Hybrid-Bridge-Based DAB Converter With Voltage Match Control for Wide Voltage Conversion Gain Application," in IEEE Transactions on Power Electronics, vol. 33, no. 2, pp. 1378-1388, Feb. 2018 